\title{
Mechanisms of Change in Digital Health Interventions for Mental Disorders in Youth: Systematic Review
}

Matthias Domhardt ${ }^{1}, \mathrm{MSc}$; Sophie Engler ${ }^{1}, \mathrm{BSc}$; Hannah Nowak ${ }^{1}, \mathrm{MSc}$; Arne Lutsch ${ }^{1}$, BSc; Amit Baumel ${ }^{2}, \mathrm{PhD}$; Harald Baumeister ${ }^{1}, \mathrm{PhD}$

${ }^{1}$ Department of Clinical Psychology and Psychotherapy, Ulm University, Ulm, Germany

${ }^{2}$ Department of Community Mental Health, University of Haifa, Haifa, Israel

Corresponding Author:

Matthias Domhardt, MSc

Department of Clinical Psychology and Psychotherapy

Ulm University

Lise-Meitner-Str. 16

Ulm, D-89081

Germany

Phone: 497315032803

Fax: 497315032809

Email: matthias.domhardt@uni-ulm.de

\section{Abstract}

Background: Digital health interventions (DHIs) are efficacious for several mental disorders in youth; however, integrated, evidence-based knowledge about the mechanisms of change in these interventions is lacking.

Objective: This systematic review aims to comprehensively evaluate studies on mediators and mechanisms of change in different DHIs for common mental disorders in children and adolescents.

Methods: A systematic literature search of the electronic databases Cochrane Central Register of Controlled Trials, Embase, MEDLINE, and PsycINFO was conducted, complemented by backward and forward searches. Two independent reviewers selected studies for inclusion, extracted the data, and rated the methodological quality of eligible studies (ie, risk of bias and 8 quality criteria for process research).

Results: A total of 25 studies that have evaluated 39 potential mediators were included in this review. Cognitive mediators were the largest group of examined intervening variables, followed by a broad range of emotional and affective, interpersonal, parenting behavior, and other mediators. The mediator categories with the highest percentages of significant intervening variables were the groups of affective mediators $(4 / 4,100 \%)$ and combined cognitive mediators $(13 / 19,68 \%)$. Although more than three-quarters of the eligible studies met 5 or more quality criteria, causal conclusions have been widely precluded.

Conclusions: The findings of this review might guide the empirically informed advancement of DHIs, contributing to improved intervention outcomes, and the discussion of methodological recommendations for process research might facilitate mediation studies with more pertinent designs, allowing for conclusions with higher causal certainty in the future.

(J Med Internet Res 2021;23(11):e29742) doi: $\underline{10.2196 / 29742}$

\section{KEYWORDS}

children and adolescents; mental disorders; mediator; mechanisms of change; digital health intervention; psychotherapy; mobile phone

\section{Introduction}

\section{Background}

Mental disorders in children and adolescents are common, with prevalence rates ranging from $10 \%$ to $20 \%$ worldwide [1]. These disorders contribute substantially to the global burden of disease in youth [2], and about half of all mental disorders across the life span have their onset in adolescence [3]. Hence, early psychotherapeutic interventions are essential to counteract the risk of chronification and prevent possible negative long-term effects [1]. However, a substantial proportion of children and adolescents with mental disorders do not receive adequate psychotherapeutic or psychosocial care [4-6] owing to different 
individual and structural barriers to treatment uptake [7]. Furthermore, the availability of mental health care is often insufficient to adequately meet treatment demands, particularly in rural regions [8] and low-income countries [9].

Digital health interventions (DHIs), such as internet- and mobile-based interventions with a psychotherapeutic focus $\left(\mathrm{DHI}_{\mathrm{PSY}}\right)$, offer the possibility of addressing some barriers to treatment uptake and might contribute to extending mental health care, given their various presumed advantages, such as possible cost- and time-efficient use, independence from spatial and temporal circumstances, potential anonymity, high degrees of flexibility, and autonomy for users. These assets may be especially important during the COVID-19 pandemic and allow for continued mental health care despite contact restrictions and physical distancing [10]. Furthermore, in view of the fact that youth are particular familiar with digital devices (so-called digital natives; Children in a digital world [11]), the use of DHIs might be especially appealing to this younger age group [12]. DHIs can be distinguished and characterized based on their theoretical basis, the type of technical implementation, the area of application, and the extent of accompanying human support $[13,14]$. The type and the intensity of guidance in DHIs can vary on the continuum from (1) pure self-help interventions without any human support (so-called unguided interventions) to (2) interventions with some support (guided interventions), to (3) videoconference-based psychotherapy with the internet as the sole communication medium between therapists and patients [15].

The efficacy of $\mathrm{DHI}_{\mathrm{PSY}}$ for some common mental disorders in children and adolescents has been established using meta-analyses [12,16-19]. For example, Vigerland et al [19] evaluated the efficacy of internet-based cognitive behavioral therapy for a range of mental disorders, including anxiety, depression, behavioral problems, obsessive-compulsive disorder, and some somatic disorders such as chronic pain and insomnia. This meta-analysis revealed a moderate, aggregated effect size favoring internet-based cognitive behavioral therapy over waitlist ( $\mathrm{g}=0.62,95 \% \mathrm{CI} 0.41-0.84 ; P<.001)$. In contrast, Hollis et al [20] appraised the evidence on the efficacy of $\mathrm{DHI}_{\mathrm{PSY}}$ for other mental disorders, including attention-deficit/hyperactivity disorder, autism, psychotic disorders, and eating disorders in their review as uncertain and necessitating future research regarding moderators of intervention effects. Current empirical knowledge suggests that older children and adolescents benefit more from $\mathrm{DHI}_{\mathrm{PSY}}$ than younger children $[12,20]$. In addition, the well-established finding that guided interventions are more efficacious than unguided interventions in adults [21,22] also seems to apply for $\mathrm{DHI}_{\mathrm{PSY}}$ in youth [12,20]. Complementing the evidence base and representing another major area of application, DHIs with a focus on health promotion $\left(\mathrm{DHI}_{\mathrm{HP}}\right)$, for example, on alcohol consumption or other lifestyle and health behaviors, revealed a considerably smaller effect size (Cohen $d=0.14,95 \%$ CI 0.00-0.27) [23] when compared with $\mathrm{DHI}_{\mathrm{PSY}}$ with a genuine psychotherapeutic foundation such as cognitive behavioral therapy $(\mathrm{g}=0.72,95 \%$ CI $0.55-0.90$; $P<.001)$ [16].
Given this rather heterogeneous body of research regarding the efficacy and effectiveness of DHIs, comprising various interventions with different theoretical orientations, foci, and delivery modes, for mental health issues in children and adolescents, it seems both timely and worthwhile to investigate the presumed working mechanisms in these technology-delivered interventions. This is because evidence-based knowledge on the mediators and mechanisms of change (specific for different approaches of $\mathrm{DHI}_{\mathrm{PSY}}$ and $\mathrm{DHI}_{\mathrm{HP}}$ ) can inform intervention development and mental health care practices, illustrating pathways to more powerful intervention packages and improved outcomes [24-26]. The first step in understanding the underlying processes in DHIs is to analyze the mediators. A mediator is an intervening variable that can explain the statistical relationship between an independent variable (eg, a DHI) and a dependent variable (eg, a symptom change) [25], and can thereby potentially point to a mechanism through which an intervention achieves its effects. Although various methods for statistical mediation analysis are available (eg, MacKinnon et al [27]), comprising different approaches such as latent growth curve modeling [28] or structural equation modeling [29], the seminal approach of Baron and Kenny [30] is still one of the most applied procedures to evaluate the intervening variable effect of a potential mediator, despite having received criticism with regard to some limitations, such as low statistical power, difficulties in the assessment of multiple mediators, or quantification of the mediation effect magnitude [24]. Although statistical mediation may be established either with the so-called causal-steps approach by Baron and Kenny [30] or by more recent methods correcting some of its limitations (eg, Kraemer et al [31]), it is important to consider that mediators might be identical to a mechanism of change (ie, the actual process responsible for change), but might also be a proxy for 1 or more other variables that do not explain the hypothesized mechanism [25]. Thus, to determine the degree of validity that a mediator is actually representative of for being considered a true change mechanism, Kazdin proposed several quality criteria for psychotherapy process research [25] that can be consulted when assessing the scope and justification of causal inferences: (1) Strong association (among treatment, mediator, and outcome), (2) specificity (a mediator accounts for the indirect effect of treatment on outcome), (3) consistency (the association must be replicable), (4) experimental manipulation (use of either a randomized controlled trial [RCT] design where the intervention variable is manipulated or an experimental design where the mediator itself is directly manipulated), (5) timeline or temporality (the intervention must lead to changes in the mediator, which must temporally precede changes in the outcome), (6) gradient (ie, a dose-response relationship: greater activation of the mediator is associated with greater change in the outcome), and (7) plausibility or coherence (the proposed mediator must be embedded in a plausible theoretical framework).

The evidence base for the mediators and mechanisms of change in conventional face-to-face psychotherapies for children and adolescents is scarce, and only a few studies have been designed to investigate the therapeutic processes in these interventions 
[32]. For example, 2 systematic reviews dedicated to evaluating the mechanisms of change found that only a small number of eligible primary studies actually conducted mediation analyses, with only $9 \%(6 / 67)$ [33] and 17\% (8/46) of included clinical trials [34] attempting to evaluate mediation effects. In addition, Schmidt and Schimmelmann [35] reviewed the empirical literature on mediators in psychotherapeutic interventions for common mental disorders in youth and concluded that most eligible studies evaluated mediators referring to the parent-child interaction (eg, family cohesion and parental support), next to mediators within the patient (eg, self-efficacy, motivation, coping, interpersonal skills, as well as changes in dysfunctional cognitions and negative emotions) and characteristics of the intervention (eg, duration of treatment, number of patient-therapist contacts, and application of specific intervention techniques). The included studies revealed inconsistent patterns of mediation effects related to therapist factors, such as flexibility, adherence to treatment, or therapeutic alliance [35]. Moreover, as central conceptual and methodological requirements for mediation analyses were often not met by studies in this review, causal inferences were widely precluded, necessitating future process research with higher methodological rigor [35].

\section{Objectives}

Although research on DHIs is a fast growing field [36] and might also offer intriguing opportunities for psychotherapeutic process research [24,37], we are not aware of any systematic review of the mediators and mechanisms of change in $\mathrm{DHI}_{\mathrm{PSY}}$ and $\mathrm{DHI}_{\mathrm{HP}}$ for common mental disorders in youth published to this point. Therefore, this study aimed to: (1) systematically review the current state of research on mediators and mechanisms of change in various DHIs for mental disorders in children and adolescents, (2) identify mediators and potential mechanisms of change in these interventions, and (3) evaluate the methodological quality of eligible mediation studies according to the quality criteria for process research mentioned above.

\section{Methods}

This systematic review was reported in accordance with the PRISMA (Preferred Reporting Items for Systematic Reviews and Meta-Analyses) guidelines [38] and was a priori registered with the Open Science Framework [39].

\section{Eligibility Criteria}

Studies were eligible for inclusion if they fulfilled the following criteria: (1) participants were children (0-13 years) or adolescents (14-21 years) diagnosed with a mental disorder or exhibited clinically relevant symptoms of a mental disorder;
(2) in the case of mixed samples with adolescents and young adults, the mean age of the sample was not above 21 years; (3) the interventions were designed for children or adolescents, or for parents of children or adolescents fulfilling the first criterion; (4) the diagnosis of mental disorders was based on the diagnostic and statistical manual of mental disorders, or the International Classification of Diseases criteria and was assessed with a validated and standardized clinical interview, or a standardized self-report instrument, or standardized ratings by significant others (eg, parents, teachers, clinicians); (5) samples of mixed or comorbid mental disorders were included; (6) studies with different recruitment strategies were eligible; (7) interventions with different theoretical orientations were eligible; (8) the intervention was predominantly delivered through the internet (eg, via web browsers or mobile or smartphone apps); (9) interventions with different degrees of human guidance and completely self-guided interventions were eligible for inclusion; (10) different active and passive control groups (CGs) were included; (11) changes in the symptoms and (12) mediators were reported; (13) at least one mediation analysis was performed; (14) studies were RCTs or secondary analyses of RCTs published in a peer reviewed journal in English language.

\section{Systematic Literature Search and Study Selection}

The search strategy was 3-fold. First, systematic literature searches were conducted in the Cochrane Central Register of Controlled Trials, Embase, MEDLINE (ie, Ovid MEDLINE, Ovid MEDLINE Epub Ahead of Print, Ovid MEDLINE In-Process and Other Non-Indexed Citations, Ovid MEDLINE Daily Update), and PsycINFO databases from database inception until May 30, 2020. The search strings were built on established prior search strings $[24,40]$ further adapted to specifically meet the research questions at hand and modified for each database in Ovid (for details on all search strings, see Multimedia Appendix 1). Second, the reference lists of all eligible studies and other relevant reviews were manually searched to identify further studies that met our inclusion criteria (ie, backward searches). Third, a citation-search (ie, forward search) was conducted in the Web of Science database.

Study selection was conducted with the support of a software tool for systematic reviews [41]. Duplicates were detected automatically by the software or were manually removed. First, 1 reviewer (SE) screened titles and abstracts of all the remaining studies and discarded irrelevant articles. Second, the full texts of all potentially relevant articles were screened in terms of the aforementioned eligibility criteria independently by 2 reviewers (SE and HN). Disagreements were resolved by consultation with a third reviewer (MD). The full process of the systematic literature search and study selection is displayed in the PRISMA flowchart of Figure 1. 
Figure 1. PRISMA (Preferred Reporting Items for Systematic Reviews and Meta-Analyses) flowchart.
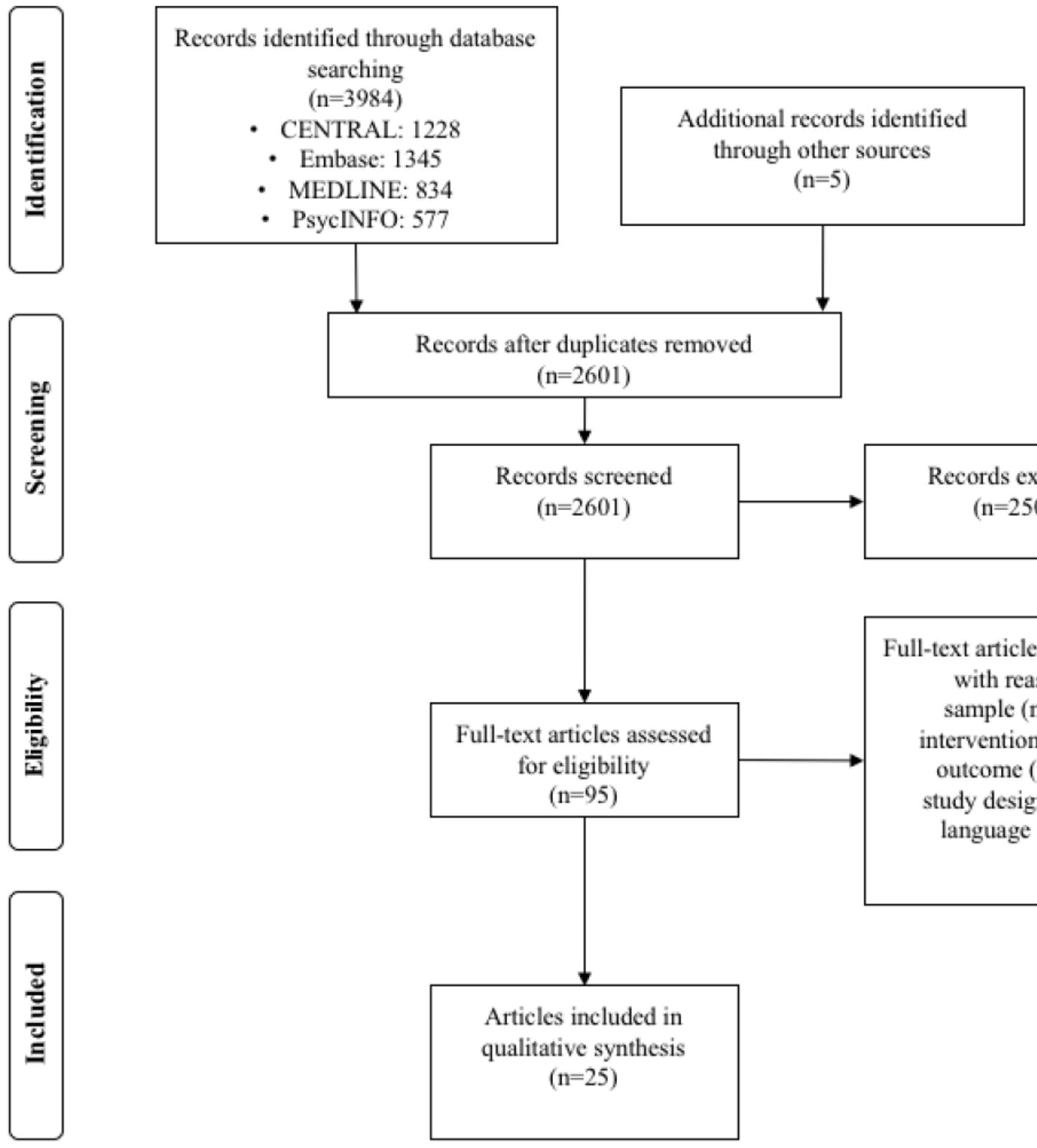

Full-text articles excluded, with reasons sample $(\mathrm{n}=18)$ intervention $(\mathrm{n}=22)$ outcome $(\mathrm{n}=27)$ study design $(\mathrm{n}=2)$ language $(\mathrm{n}=1)$

\section{Data Extraction}

Two independent reviewers (SE and HN) extracted the following data: study information items (name of first author, country, and year), sample information (sample size and age), intervention characteristics (theoretical orientation, number of modules, and duration of intervention), information about control conditions, and information about outcomes (mediator type, instrument, and statistical analysis of mediation). Authors were contacted via email in case of missing information essential for decisions on study selection and the application of the systematic review.

\section{Categorization of Studies}

The included studies were divided into 2 categories: studies evaluating interventions with a psychotherapeutic focus (ie, $\mathrm{DHI}_{\mathrm{PSY}}$ ) and studies evaluating interventions with a focus on health promotion (comprising interventions targeting health behavior, lifestyle, and behavior change interventions for the purpose of primary and secondary prevention; ie, $\left.\mathrm{DHI}_{\mathrm{HP}}\right)$. Of note, interventions with rehabilitation or tertiary prevention focus were not included.

\section{Quality Assessment}

\section{Risk-of-Bias Assessment}

The methodological quality of the included studies was assessed independently by 2 reviewers (SE and $\mathrm{HN}$ ) using the Cochrane risk-of-bias (RoB) tool for randomized trials (version 2, RoB2; [42]) on 5 domains: (1) bias arising from the randomization process, (2) bias due to deviations from intended interventions, (3) bias due to missing outcome data, (4) bias in measurement of the outcomes, and (5) bias in selection of the reported result. The included studies were rated as having low, unclear, or high $R o B$ in each domain [42]. Interrater reliability was calculated using the Cohen $\kappa$ in RStudio (version 1.2.1335; [43]). 


\section{Quality Criteria for Process Research and Approximating Causality}

The included studies were rated by 2 independent reviewers (SE and HN). The rating system was based on Kazdin's [25] initial criteria to approach causality, modified by Domhardt et al [24] and Lemmens et al [44]. To meet the respective criteria, studies had to: (1) use an appropriate RCT design, (2) include a CG, (3) report a theoretical foundation for mediators, (4) have a minimum sample size of 40 participants per group, (5) examine multiple mediators within 1 study, (6) assess temporality (3 or more assessments of the mediator variables and outcomes), (7) experimentally manipulate the mediator, and (8) reveal a strong statistical association among intervention, mediator, and outcome (operationalized as statistical significance of $P<.05$, as suggested by Moreno-Peral et al [45]). All criteria were rated as fulfilled or not fulfilled. In accordance with prior research $[24,44]$, criteria specificity, consistency, and gradient were not assessed, as they are not meaningfully applicable in single studies (consistency) or are too exclusive for some therapeutic processes (gradient and specificity).

\section{Results}

\section{Study Characteristics}

Altogether, data from $25(k=25)$ publications were analyzed [46-70]. Specifically, $52 \%(13 / 25)$ of the studies $[46,47,49,54,56,58-60,64-67,69]$ evaluated DHI $_{\mathrm{PSY}}$ and $48 \%$ $(12 / 25)$ of the studies evaluated $\mathrm{DHI}_{\mathrm{HP}}$ $[48,50-53,55,57,61-63,68,70]$. In the studies, a total of 4884 participants were randomized. Studies on $\mathrm{DHI}_{\mathrm{PSY}}$ accounted for $43.2 \%$ (2110/4884) of participants, and studies on $\mathrm{DHI}_{\mathrm{HP}}$ accounted for $56.8 \%$ (2774/4884) of participants. The overall sample sizes varied from 51 [59] to 818 [63]. The median publication year was 2014 (2002 [48] to 2020 [49]). Most studies were conducted in the United States $(17 / 25,68 \%)$, and most of the study participants were female $(2985 / 4884,61.18 \%)$. In 1 study, no information was provided regarding the distribution of sex [54]. The mean age of participants was 18.49 (SD 2.01) years. The lowest mean age was 5.4 (SD 2.2) years [67], and the highest was 21.02 (SD 2.16) years [70]. Participants were younger in studies evaluating $\mathrm{DHI}_{\mathrm{PSY}}$ compared with participants in studies evaluating $\mathrm{DHI}_{\mathrm{HP}}$ (17.11 vs 19.67 years). The exact information on the average age of the final sample was not provided in 4 studies $[54,56,63,68]$. Most interventions took place without parental involvement and were directed at the youth themselves $(20 / 25,80 \%)$. In $20 \%$ (5/25) of the studies, interventions for children [54,67] as well as interventions for both children and adolescents $[46,65]$ and for adolescents only [64] were evaluated with the involvement of parents (including intervention components for parents or parent training). Demographic information about the parents who participated was provided in $16 \%(4 / 25)$ of the studies $[46,54,65,67]$. Study participants were recruited predominantly from educational or health-related settings $(15 / 25,60 \%)$. In $32 \%(8 / 25)$ of the studies, participants were made aware of the study through both web-based advertising (including social media and websites) and conventional advertising (including letters and flyers). To identify potential participants, one study $(1 / 25,4 \%)$ used data from a mass web-based survey [59]. Information on recruitment strategy could not be identified in $4 \%(1 / 25)$ of the studies [68]. Across studies, the average study dropout rate accounted for $18 \%$ (range $0 \%$ [62] to $39.3 \%$ [54]). In $4 \%(1 / 25)$ of the studies, the dropout rate was not reported [46].

The interventions were directed toward a broad range of mental health problems, including risky drinking behavior (including risky or heavy drinking and binge drinking; 11/25, 44\%), depressive disorders $(5 / 25,20 \%)$, anxiety disorders (including separation anxiety, generalized anxiety disorder, social phobia, and specific phobia; $3 / 25,12 \%)$, behavioral problems $(2 / 25$, $8 \%)$, and insomnia $(1 / 25,4 \%)$. Furthermore, $12 \%(3 / 25)$ of the studies evaluated interventions that addressed multiple disorders simultaneously (ie, transdiagnostic interventions). De Bruin et al [47] addressed transdiagnostic psychopathological abnormalities (including affective, anxiety, and somatic problems; problems concerning attention-deficit/hyperactivity disorder; oppositional defiant behavior; and conduct problems). Levin et al [60] addressed psychological problems such as depressive disorders, generalized anxiety disorder, social phobia, alcohol consumption, academic worries, worries concerning eating, hostility, and negative stress. Another intervention addressed depression, anxiety, and stress [56]. Of note, there were 2 interventions evaluated and applied in more than 1 study (the $e$-CHUG interventions in 4 studies; and the BRAVE interventions in 2 studies), but the investigated mediators differed in all studies; thus, these publications were regarded as distinct entities and single studies (see Multimedia Appendix 2 [46-70] for details).

Internet-based interventions were evaluated in 92\% (12/13) of the studies on $\mathrm{DHI}_{\mathrm{PSY}}$. Most interventions were based on the components of cognitive behavioral therapy $[46,47,49,59,66]$. In addition, relaxation strategies, such as progressive muscle relaxation and autogenic training [49], and elements of social learning theory [54] were deployed. Further interventions were based on the acceptance and commitment therapy [60], components of systemic family therapy, problem solving and communication training, cognitive restructuring, and alternative family roles [64]. One intervention [56] was based on the temporal model of control. In $23 \%$ (3/13) of the studies, precise information on the theoretical orientation and background of the intervention was not available [58,67,69]. Moreover, 7\% (1/13) of the studies evaluated a mobile-based intervention based on a self-monitoring program [58].

All $\mathrm{DHI}_{\mathrm{HP}}$ studies were internet-based and included a feedback component $(12 / 12,100 \%)$. The so-called $e-C H U G$ tool was evaluated in 33\% (4/12) of the studies [51,57,62,68]. Feedback was provided via email $[48,53]$ or in person using a motivational interviewing approach [51,52]. In addition to the feedback components, cognitive components such as expressive writing [70] and retrieval of remembered information from feedback were evaluated [57]. A detailed overview of the study characteristics is provided in Multimedia Appendix 2.

\section{Mediators}

An overview of the classification of mediators and their empirical support is provided in Table 1. A total of 39 potential 
mediators were investigated in the included RCTs. Among these, more than half of the mediators were evaluated as significant $(21 / 39,54 \%)$. With $48 \%$ (19/39) intervening variables, the largest group of all examined intervening variables was of a cognitive nature. A total of 13 cognitive mediators were evaluated as significant in the primary studies $(13 / 19,68 \%)$. We further divided the group of cognitive mediators into the assessment (examined: 8/39, 20\%; significant: 5/8), motivation (examined: $1 / 39,2 \%$; significant: $0 / 1,0 \%$ ) and cognitive processes subcategories (examined: 10/39, 25\%; significant: $8 / 10,80 \%$ ). Further evenly investigated mediator categories were emotional/affective (examined: 4/39, 10\%; significant: 4/4, 100\%), interpersonal (examined: 4/39, 10\%; significant: $1 / 4,25 \%$ ), and parenting behavior mediators (examined: $4 / 39$, $10 \%$; significant: $0 / 4,0 \%$ ). The second largest group of mediators was not clearly classifiable into one of the aforementioned categories and was thus subsumed into a separate other mediator category (examined: 8/39, 20\%; significant: $3 / 8,38 \%$ ). Of note, a Wilcoxon rank-sum test revealed no difference in the sample sizes between studies that found at least one significant mediator and studies that found no significant mediator (W $\{19,6\}=59 ; P=.93$ ). 
Table 1. Classification of mediators.

\begin{tabular}{|c|c|c|c|c|c|c|c|}
\hline Mediators & $\begin{array}{l}\text { Studies, } \mathrm{n} \\
(\%)(\mathrm{n}=25)\end{array}$ & Age (years), range $^{a}$ & Guidance & Disorder & Effect size ${ }^{b}$ & Significance & $\begin{array}{l}\text { Criteria } \\
\text { met } \geq 5\end{array}$ \\
\hline \multicolumn{8}{|c|}{ Emotional and affective mediators } \\
\hline $\begin{array}{l}\text { Emotional self- } \\
\text { perception }\end{array}$ & $1(4)$ & $14-22$ & Unguided & Depression & $\begin{array}{l}\text { Partially stan- } \\
\text { dardized }\end{array}$ & Yes & $(+)^{\mathrm{d}}$ \\
\hline & & & & & $\begin{array}{l}E S^{\mathrm{c}}=-1.049 \\
(95 \% \text { CI } \\
-1.35 \text { to } \\
-0.755)\end{array}$ & & \\
\hline Fear & $1(4)$ & $16-24$ & $\begin{array}{l}\text { Internet-based } \\
\text { psychotherapy }\end{array}$ & Depression & $\begin{array}{l}\text { Between } \\
\text { groups } \\
\mathrm{ES}=0.49(95 \% \\
\mathrm{CI} 0.24 \text { to } \\
0.75)\end{array}$ & Yes & $(+)$ \\
\hline Hopelessness & $1(4)$ & $>18$ & Unguided & Depression & $\begin{array}{l}\text { Cohen } d=1.13 \\
\text { (between } \\
\text { groups follow- } \\
\text { up) }\end{array}$ & Yes & $(+)$ \\
\hline $\begin{array}{l}\text { Thought-related } \\
\text { distress }\end{array}$ & $1(4)$ & $\begin{array}{l}\text { Undergraduate stu- } \\
\text { dents }\end{array}$ & Guided self-help & $\begin{array}{l}\text { Generalized anxiety } \\
\text { disorder }\end{array}$ & $\begin{array}{l}\text { Cohen } \\
d=0.526 \text { (be- } \\
\text { tween groups } \\
\text { follow-up) }\end{array}$ & Yes & $(+)$ \\
\hline \multicolumn{8}{|c|}{ Interpersonal mediators } \\
\hline $\begin{array}{l}\text { Parent-Youth } \\
\text { conflict }\end{array}$ & $1(4)$ & $12-19$ & $\begin{array}{l}\text { Internet-based } \\
\text { psychotherapy }\end{array}$ & Depression & $-^{\mathrm{e}}$ & Yes & $(+)$ \\
\hline $\begin{array}{l}\text { Family conflicts } \\
\text { related to dia- } \\
\text { betes manage- } \\
\text { ment }\end{array}$ & $1(4)$ & $12-19$ & $\begin{array}{l}\text { Internet-based } \\
\text { psychotherapy }\end{array}$ & Depression & - & No & $(+)$ \\
\hline $\begin{array}{l}\text { Failed help or } \\
\text { negative social } \\
\text { support }\end{array}$ & $1(4)$ & $12-19$ & $\begin{array}{l}\text { Internet-based } \\
\text { psychotherapy }\end{array}$ & Depression & - & No & $(+)$ \\
\hline Social skills & $1(4)$ & $8-17$ & Guided self-help & Social phobia & - & No & $(+)$ \\
\hline \multicolumn{8}{|c|}{ Parenting behavior mediators } \\
\hline $\begin{array}{l}\text { Appropriate edu- } \\
\text { cation }\end{array}$ & $1(4)$ & $10-13$ & Guided self-help & Behavioral problems & - & No & $(+)$ \\
\hline $\begin{array}{l}\text { Skill in setting } \\
\text { clear boundaries }\end{array}$ & $1(4)$ & $10-13$ & Guided self-help & Behavioral problems & - & No & $(+)$ \\
\hline $\begin{array}{l}\text { Severity and in- } \\
\text { consistent educa- } \\
\text { tion }\end{array}$ & $1(4)$ & $10-13$ & Guided self-help & Behavioral problems & - & No & $(+)$ \\
\hline $\begin{array}{l}\text { Change in parent- } \\
\text { ing behavior }\end{array}$ & $1(4)$ & $3-9$ & Guided self-help & Behavioral problems & - & No & $(-)^{\mathrm{f}}$ \\
\hline \multicolumn{8}{|l|}{ Cognitive mediators } \\
\hline \multicolumn{8}{|l|}{ Assessment } \\
\hline $\begin{array}{l}\text { Assessment } \\
\text { of discrepan- } \\
\mathrm{cy}^{\mathrm{g}}\end{array}$ & $2^{\mathrm{g}}(8)$ & $\begin{array}{l}\text { College students; } \\
\text { College students }\end{array}$ & $\begin{array}{l}\text { Guided self-help; } \\
\text { guided self-help }\end{array}$ & $\begin{array}{l}\text { Risky drinking be- } \\
\text { havior }\end{array}$ & $-;-$ & No & $(+)$ \\
\hline $\begin{array}{l}\text { Assessment } \\
\text { of peer } \\
\text { drinking be- } \\
\text { havior }^{\mathrm{g}}\end{array}$ & $2^{\mathrm{g}}(8)$ & $18-24 ; 18-24$ & $\begin{array}{l}\text { Guided self-help; } \\
\text { guided self-help }\end{array}$ & $\begin{array}{l}\text { Risky drinking be- } \\
\text { havior }\end{array}$ & $-;-$ & Yes & $\begin{array}{l}\text { Different } \\
\text { result }\end{array}$ \\
\hline
\end{tabular}




\begin{tabular}{|c|c|c|c|c|c|c|c|}
\hline Mediators & $\begin{array}{l}\text { Studies, } \mathrm{n} \\
(\%)(\mathrm{n}=25)\end{array}$ & Age (years), range ${ }^{a}$ & Guidance & Disorder & Effect size ${ }^{b}$ & Significance & $\begin{array}{l}\text { Criteria } \\
\text { met } \geq 5\end{array}$ \\
\hline $\begin{array}{l}\text { Perceived } \\
\text { norm }^{\mathrm{g}}\end{array}$ & $4^{g}(16)$ & $\begin{array}{l}\text { 18-25; Students; } \\
\text { First semester stu- } \\
\text { dents; } 18-26\end{array}$ & $\begin{array}{l}\text { Guided self-help; } \\
\text { unguided; guided } \\
\text { self-help; unguid- } \\
\text { ed }\end{array}$ & $\begin{array}{l}\text { Risky drinking be- } \\
\text { havior }\end{array}$ & $\begin{array}{l}\text {-; Cohen } \\
d=-0.2(\mathrm{ES} \\
\text { Biannual);-; } \\
-\end{array}$ & $\begin{array}{l}\text { Different re- } \\
\text { sults }^{\mathrm{h}}\end{array}$ & $(+)$ \\
\hline
\end{tabular}

\section{Motivation}

$\begin{array}{llll}\begin{array}{l}\text { Motivation } \\ \text { to change }\end{array} & \text { College students } & \text { Unguided } & \begin{array}{l}\text { Risky drinking be- } \\ \text { havior }\end{array} \\ \text { drinking be- } & & \\ \text { havior } & & \end{array}$

havior

\section{Cognitive processes}

\begin{tabular}{|c|c|c|c|c|c|c|}
\hline $\begin{array}{l}\text { Alcohol-re- } \\
\text { lated expecta- } \\
\text { tions }\end{array}$ & - & Students & Guided self-help & $\begin{array}{l}\text { Risky drinking be- } \\
\text { havior }\end{array}$ & - & Yes \\
\hline $\begin{array}{l}\text { Remem- } \\
\text { bered infor- } \\
\text { mation }\end{array}$ & $1(4)$ & Students & Guided self-help & $\begin{array}{l}\text { Risky drinking be- } \\
\text { havior }\end{array}$ & - & Yes \\
\hline Mastering & $1(4)$ & $16-25$ & $\begin{array}{l}\text { Internet-based } \\
\text { psychotherapy }\end{array}$ & Depression & $\begin{array}{l}\text { Between } \\
\text { groups } \\
\text { ES=0.94 }(95 \% \\
\text { CI } 0.64 \text { to } \\
1.23)\end{array}$ & Yes \\
\hline $\begin{array}{l}\text { Willingness } \\
\text { to cope }\end{array}$ & - & Students & Unguided & Depression & - & No \\
\hline $\begin{array}{l}\text { Cognitive } \\
\text { arousal be- } \\
\text { fore falling } \\
\text { asleep }\end{array}$ & $1(4)$ & Students & Unguided & Insomnia & - & No \\
\hline $\begin{array}{l}\text { Sleep-related } \\
\text { cognition }\end{array}$ & - & Students & Unguided & Insomnia & - & Yes \\
\hline $\begin{array}{l}\text { Postevent } \\
\text { processing }\end{array}$ & $1(4)$ & $8-17$ & Guided self-help & Social phobia & - & Yes \\
\hline $\begin{array}{l}\text { Mindful ac- } \\
\text { ceptance }\end{array}$ & $1(4)$ & Students & Guided self-help & Transdiagnostic ${ }^{\mathrm{i}}$ & $\begin{array}{l}\text { Proportion } \\
\text { mediated } \\
\text { ES=range } \\
16.05 \% \text { to } \\
28.57 \%\end{array}$ & Yes \\
\hline $\begin{array}{l}\text { Obstruction } \\
\text { of apprecia- } \\
\text { tion of life }\end{array}$ & - & Students & Guided self-help & Transdiagnostic $^{\mathrm{i}}$ & $\begin{array}{l}\text { Proportion } \\
\text { mediated } \\
\text { ES=range } \\
29.18 \% \text { to } \\
57.94 \%\end{array}$ & Yes \\
\hline $\begin{array}{l}\text { Perceived } \\
\text { control }\end{array}$ & $1(4)$ & $18-21$ & Guided self-help & Transdiagnostic ${ }^{\mathrm{i}}$ & $\begin{array}{l}\text { Cohen } \\
d=0.07 ; \text { Co- } \\
\text { hen } d=0.59 ; \\
\text { Cohen } d=0.66 \\
\text { (between } \\
\text { groups follow- } \\
\text { up) }\end{array}$ & Yes \\
\hline
\end{tabular}

Yes

Other

$\begin{array}{llllllll}\begin{array}{l}\text { Alcohol consump- } \\ \text { tion as coping be- } \\ \text { havior }\end{array} & 1(4) & 18-21 & \text { Unguided } & \begin{array}{l}\text { Risky drinking be- } \\ \text { havior }\end{array} & \text { No } & \text { (+) } \\ \begin{array}{l}\text { Therapy adher- } \\ \text { ence }\end{array} & 1(4) & 7-18 & \text { Guided self-help } & \text { Anxiety disorder } & - & \text { No } & (-) \\ \text { Eating disorder } & 1(4) & 18-25 & \text { Unguided } & \text { Depression } & - & \text { Yes } & (+)\end{array}$




\begin{tabular}{|c|c|c|c|c|c|c|c|}
\hline Mediators & $\begin{array}{l}\text { Studies, } \mathrm{n} \\
(\%)(\mathrm{n}=25)\end{array}$ & Age (years), range ${ }^{a}$ & Guidance & Disorder & Effect size $^{b}$ & Significance & $\begin{array}{l}\text { Criteria } \\
\text { met } \geq 5\end{array}$ \\
\hline $\begin{array}{l}\text { Overall sleep } \\
\text { quality }\end{array}$ & $1(4)$ & Students & Unguided & Insomnia & - & No & $(+)$ \\
\hline Chronotypical & $1(4)$ & Students & Unguided & Insomnia & - & No & $(+)$ \\
\hline $\begin{array}{l}\text { Physical arousal } \\
\text { before falling } \\
\text { asleep }\end{array}$ & $1(4)$ & Students & Unguided & Insomnia & - & Yes & $(+)$ \\
\hline $\begin{array}{l}\text { Trauma-related } \\
\text { sleeping disorder }\end{array}$ & $1(4)$ & Students & Unguided & Insomnia & - & No & $(+)$ \\
\hline Insomnia & $1(4)$ & $12-19$ & Guided self-help & Transdiagnostic ${ }^{\mathrm{i}}$ & - & Yes & $(+)$ \\
\hline
\end{tabular}

aff age range was not reported, participant group labels were used.

${ }^{\mathrm{b}}$ Effect size measures differed across studies.

${ }^{\mathrm{c}} \mathrm{ES}$ : effect size

${ }^{\mathrm{d}}$ Met 5 or more criteria.

Not available.

${ }^{\mathrm{f}}$ Met fewer than 5 criteria.

gIf mediator was assessed in more than 1 study, data and results were separated with ";",

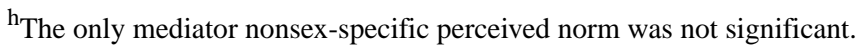

${ }^{\mathrm{i}}$ Transdiagnostic intervention targets more than one disorder.

A broad range of different approaches to mediation analyses was deployed, with some studies relying on several strategies at once. Bootstrapping (eg, Preacher and Hayes [71]) was used in almost half of the studies $(11 / 25,44 \%)$. In $32 \%(8 / 25)$ of the studies, the mediation analysis was based on the approach of Baron and Kenny [30], and in addition, 8\% (2/25) performed a Sobel test. Furthermore, $32 \%(8 / 25)$ of the mediation analyses were performed using structural equation modeling $(7 / 25,28 \%$ using the MPlus software). Moreover, $4 \%(1 / 25)$ of the studies performed multiple regression analysis according to the Judd and colleagues paradigm [72], and another study did not provide any information on the statistical analysis.

\section{Quality Assessment of Included Studies}

\section{Risk-of-Bias Assessment}

As illustrated in the RoB2 Graph (Figure 2), approximately three-quarters $(19 / 25,76 \%)$ of the included studies were rated as having a high RoB. In more than half of the studies (14/25, $56 \%$ ), the bias due to deviation from the intended intervention was rated as high. The RoB on this domain was more often evaluated to be high in studies on $\mathrm{DHI}_{\mathrm{HP}}(10 / 25,40 \%)$ when compared with studies on $\mathrm{DHI}_{\mathrm{PSY}}(4 / 25,16 \%)$. Both the randomization procedure and the process of reporting results were predominantly rated with some concern across studies $(19 / 25,76 \%$ and $22 / 25,88 \%)$. Interrater reliability varied across domains from Cohen $\kappa=0.76$ to Cohen $\kappa=0.93$. According to Landis and Koch [73], these agreements can be rated as substantial to almost perfect. A summary of the RoB2 assessments is shown in Figure 3.

Figure 2. Risk-of-bias graph.

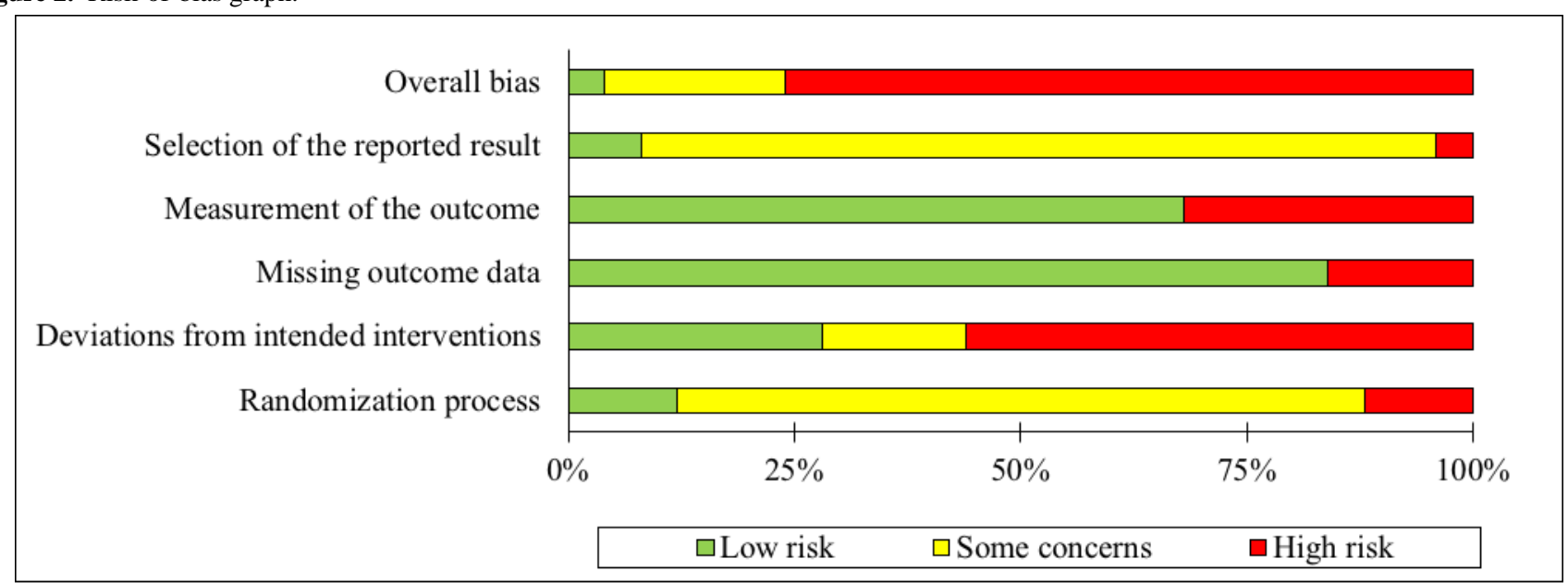


Figure 3. Risk-of-bias summary.

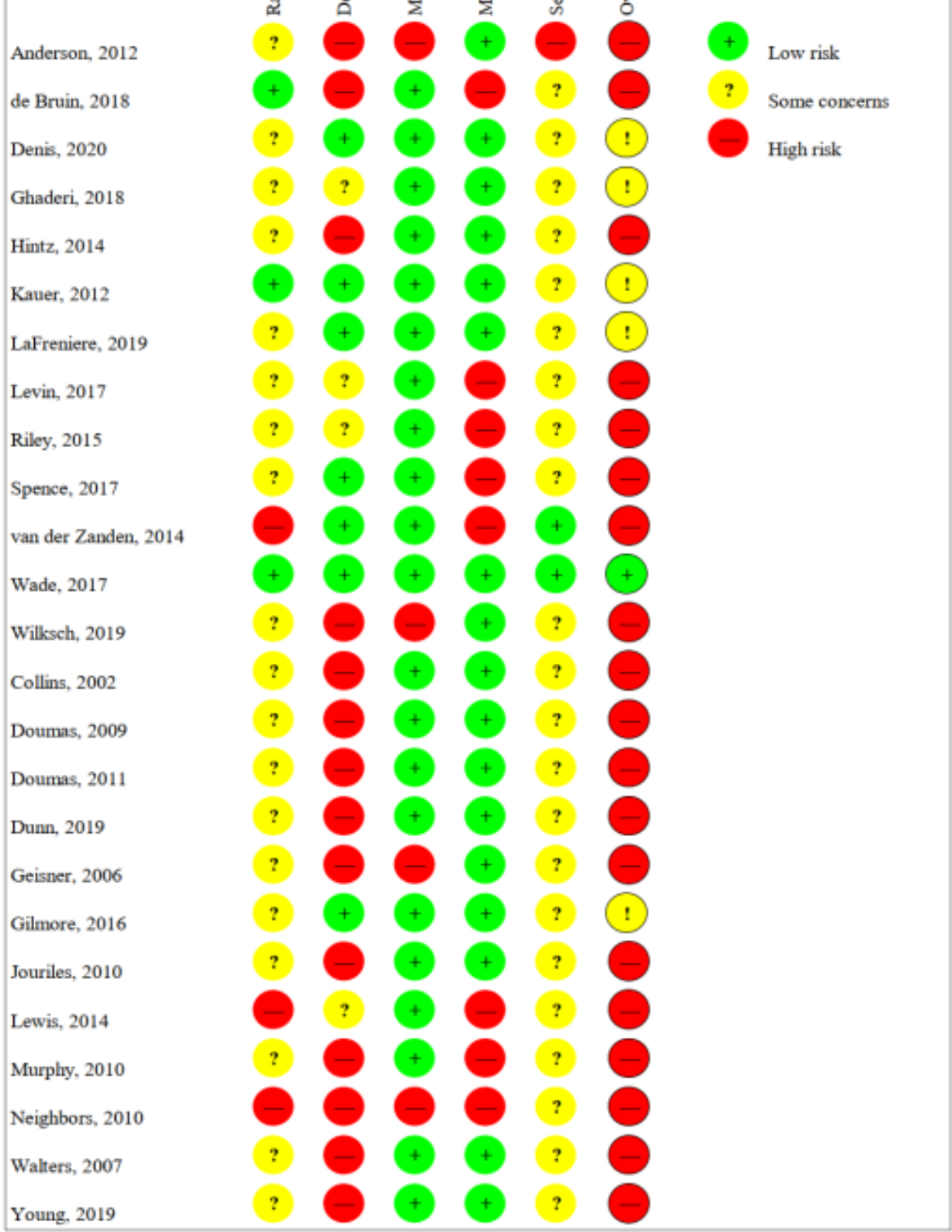

\section{Evaluation of the Quality Criteria for Process Research and Approximating Causality}

The evaluation of the included studies with regard to the methodological quality of process research revealed that in both the $\mathrm{DHI}_{\mathrm{PSY}}$ and the $\mathrm{DHI}_{\mathrm{HP}}$ groups, most studies $\left(\mathrm{DHI}_{\mathrm{PSY}}: 9 / 13\right.$, $69 \%$ vs $\mathrm{DHI}_{\mathrm{HP}}: 11 / 12,92 \%$ ) fulfilled 5 or more out of the 8 criteria. Owing to the eligibility criteria used in this review, almost all studies met the requirement of an RCT design (24/25,
$96 \%)$ and a CG $(24 / 25,96 \%)$. In the publication by Anderson et al [46], the results from $8 \%(2 / 25)$ of the studies were jointly reported, with only the second study evaluating a $\mathrm{DHI}_{\mathrm{PSY}}$ without a direct comparison with the $\mathrm{CG}$, although this criterion was fulfilled in the first study. Even if mediators were collected at more than 2 measurement time points in more than half of the studies (15/25, 60\%; including follow-up), an evaluation of the chronology of changes in the mediator variable or variables and outcomes was conducted in only $4 \%(1 / 25$; de Bruin et al 
[47]) of the studies. Furthermore, $8 \%$ (2/25) of the studies, Hintz et al [56] and Jouriles et al [57] implemented direct experimental manipulation of mediators. A detailed overview of the evaluation of the methodological quality criteria for process research and the approximation of causality are outlined in Tables 2 and 3, as well as in Multimedia Appendix 3. 
Table 2. Quality criteria for process research and approximation of causality $(n=25)$.

\begin{tabular}{|c|c|c|c|c|c|c|c|c|c|c|}
\hline Studies & & $\begin{array}{l}\text { Random- } \\
\text { ized con- } \\
\text { trolled trial }\end{array}$ & $\mathrm{CG}^{\mathrm{a}}$ & $\begin{array}{l}\text { Theoretical } \\
\text { foundation }\end{array}$ & $\begin{array}{l}\mathrm{n} \geq 40 \\
(\text { Each } \mathrm{CG} \\
\text { and } \mathrm{EG}^{\mathrm{b}} \text { ) }\end{array}$ & $\begin{array}{l}\text { Various } \\
\text { mediators }\end{array}$ & $\begin{array}{l}\text { Time se- } \\
\text { quence }\end{array}$ & $\begin{array}{l}\text { Manipula- } \\
\text { tion }\end{array}$ & $\begin{array}{l}P \text { value } \\
(<.05)^{\mathrm{c}}\end{array}$ & $\sum$ (Yes) \\
\hline \multicolumn{11}{|c|}{$\mathrm{DHI}_{\mathrm{PSY}}{ }^{\mathrm{d}}$} \\
\hline & $\begin{array}{l}\text { Anderson, } \\
2012[46]^{\mathrm{e}}\end{array}$ & $\mathrm{No}^{\mathrm{f}}$ & No & Yes $^{g}$ & No & No & No & No & Yes & 2 \\
\hline & $\begin{array}{l}\text { de Bruin et } \\
\text { al [47] }\end{array}$ & Yes & Yes & Yes & No & No & Yes & No & Yes & 5 \\
\hline & $\begin{array}{l}\text { Denis et al } \\
\text { [49] }\end{array}$ & Yes & Yes & No & Yes & Yes & $\mathrm{No}^{\mathrm{h}}$ & No & Yes & 5 \\
\hline & $\begin{array}{l}\text { Ghaderi et } \\
\text { al [54] }\end{array}$ & Yes & Yes & Yes $^{\mathrm{i}}$ & Yes & Yes & $\mathrm{No}^{h}$ & No & Yes & 6 \\
\hline & $\begin{array}{l}\text { Hintz, } 2014 \\
{[56]}\end{array}$ & Yes & Yes & Yes & Yes & No & $\mathrm{No}^{h}$ & Yes & Yes & 6 \\
\hline & $\begin{array}{l}\text { Kauer et al } \\
{[58]}\end{array}$ & Yes & Yes & Yes & Yes & No & $\mathrm{No}^{h}$ & No & Yes & 5 \\
\hline & $\begin{array}{l}\text { LaFreniere, } \\
\text { and New- } \\
\text { man [59] }\end{array}$ & Yes & Yes & Yes & No & No & $\mathrm{No}^{h}$ & No & Yes & 4 \\
\hline & $\begin{array}{l}\text { Levin et al } \\
{[60]}\end{array}$ & Yes & Yes & No & No & Yes & No & No & Yes & 4 \\
\hline & $\begin{array}{l}\text { Riley et al } \\
{[64]}\end{array}$ & $\mathrm{Yes}^{\mathrm{j}}$ & $\mathrm{Yes}^{\mathrm{j}}$ & Yes & Yes & Yes & $\mathrm{No}^{h}$ & No & Yes & 6 \\
\hline & $\begin{array}{l}\text { Spence et } \\
\text { al [65] }\end{array}$ & Yes & Yes & Yes & No & Yes & $\mathrm{No}^{\mathrm{h}, \mathrm{k}}$ & No & Yes & 5 \\
\hline & $\begin{array}{l}\text { Wade et al } \\
{[67]}\end{array}$ & Yes & Yes & Yes & $\mathrm{No}^{\mathrm{i}}$ & No & $\mathrm{No}^{h}$ & No & Yes & 4 \\
\hline & $\begin{array}{l}\text { Wilksch, } \\
\text { O'Shea, } \\
\text { and Wade } \\
\text { [69] }\end{array}$ & Yes & Yes & Yes & Yes & No & $\mathrm{No}^{h}$ & No & Yes & 5 \\
\hline \multicolumn{11}{|l|}{$\mathrm{DHI}_{\mathrm{HP}}{ }^{\mathrm{l}}$} \\
\hline & $\begin{array}{l}\text { Collins, } \\
\text { Carey, and } \\
\text { Sliwinski } \\
{[48]}\end{array}$ & Yes & Yes & Yes & Yes & No & $\mathrm{No}^{h}$ & No & Yes & 5 \\
\hline & $\begin{array}{l}\text { Doumas, } \\
\text { McKinley, } \\
\text { and Book } \\
{[50]}\end{array}$ & Yes & Yes & Yes & No & No & No & No & Yes & 4 \\
\hline & $\begin{array}{l}\text { Doumas et } \\
\text { al [51] }\end{array}$ & Yes & Yes & Yes & Yes & No & No & No & Yes & 5 \\
\hline & $\begin{array}{l}\text { Dunn, } 2019 \\
{[52]}\end{array}$ & Yes & Yes & Yes & Yes & No & No & No & Yes & 5 \\
\hline & $\begin{array}{l}\text { Geisner, } \\
\text { Neighbors, } \\
\text { and } \\
\text { Larimer } \\
\text { [53] }\end{array}$ & Yes & Yes & Yes & Yes & Yes & No & No & Yes & 6 \\
\hline
\end{tabular}




\begin{tabular}{|c|c|c|c|c|c|c|c|c|c|c|}
\hline Studies & & $\begin{array}{l}\text { Random- } \\
\text { ized con- } \\
\text { trolled trial }\end{array}$ & $\mathrm{CG}^{\mathrm{a}}$ & $\begin{array}{l}\text { Theoretical } \\
\text { foundation }\end{array}$ & $\begin{array}{l}\mathrm{n} \geq 40 \\
(\text { Each } C G \\
\left.\text { and } \mathrm{EG}^{\mathrm{b}}\right)\end{array}$ & $\begin{array}{l}\text { Various } \\
\text { mediators }\end{array}$ & $\begin{array}{l}\text { Time se- } \\
\text { quence }\end{array}$ & $\begin{array}{l}\text { Manipula- } \\
\text { tion }\end{array}$ & $\begin{array}{l}P \text { value } \\
(<.05)^{\mathrm{c}}\end{array}$ & $\sum(\mathrm{Yes})$ \\
\hline & $\begin{array}{l}\text { Gilmore } \\
\text { and Boun- } \\
\text { tress [55] }\end{array}$ & Yes & Yes & Yes & Yes & No & No & No & Yes & 5 \\
\hline & $\begin{array}{l}\text { Jouriles et } \\
\text { al [57] }\end{array}$ & Yes & Yes & Yes & No & No & No & Yes & Yes & 5 \\
\hline & $\begin{array}{l}\text { Lewis et al } \\
\text { [61] }\end{array}$ & Yes & Yes & Yes & Yes & No & $\mathrm{No}^{h}$ & No & Yes & 5 \\
\hline & $\begin{array}{l}\text { Murphy, } \\
2010[62]^{\mathrm{h}}\end{array}$ & Yes & Yes & Yes & Yes & Yes & $\mathrm{No}^{\mathrm{h}}$ & No & Yes & 6 \\
\hline & $\begin{array}{l}\text { Neighbors } \\
\text { et al [63] }\end{array}$ & Yes & Yes & Yes & Yes & Yes & $\mathrm{No}^{\mathrm{h}}$ & No & Yes & 6 \\
\hline & $\begin{array}{l}\text { Walters, } \\
\text { Vader, and } \\
\text { Harris [68] }\end{array}$ & Yes & Yes & Yes & $\mathrm{Yes}^{\mathrm{m}}$ & No & $\mathrm{No}^{h}$ & No & Yes & 5 \\
\hline & $\begin{array}{l}\text { Young and } \\
\text { Neighbors } \\
{[70]}\end{array}$ & Yes & Yes & Yes & Yes & No & No & No & Yes & 5 \\
\hline
\end{tabular}

${ }^{\mathrm{a}} \mathrm{CG}$ : control group.

${ }^{\mathrm{b}} \mathrm{EG}$ : experimental group.

${ }^{\mathrm{c}}$ Overall significance level $P<.05$; only data from study 2 taken into account.

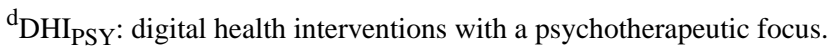

${ }^{\mathrm{e}}$ Only data from study 2 are taken into account.

${ }^{\mathrm{f}} \mathrm{No}$ indicates criteria not met.

${ }^{\mathrm{g}}$ Yes indicates criteria met.

${ }^{\mathrm{h}}$ More than 2 measurements (including follow-up) reported, but no evaluation of time sequence.

${ }^{\mathrm{i}}$ Subscales have no theoretical foundations.

${ }^{\mathrm{j}}$ Initial study had a randomized controlled trial design; in secondary analysis, both groups were taken together.

${ }^{\mathrm{k}}$ Due to missing follow-up data in the waitlist condition, mediation analysis was conducted only with data from baseline and after 12 weeks (at least 3 sessions were completed).

${ }^{\mathrm{l}} \mathrm{DHI}_{\mathrm{HP}}$ : digital health interventions with a focus on health promotion.

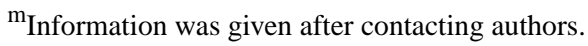

Table 3. Number of studies meeting each single quality criterion for process research $(n=25)$.

\begin{tabular}{|c|c|c|c|}
\hline Criterion & $\mathrm{DHI}_{\mathrm{PSY}}{ }^{\mathrm{a}}, \mathrm{n}(\%)$ & $\mathrm{DHI}_{\mathrm{HP}}{ }^{\mathrm{b}}, \mathrm{n}(\%)$ & Overall, n (\%) \\
\hline Randomized controlled trial & $12(48)$ & $12(48)$ & $24(96)$ \\
\hline $\mathrm{CG}^{\mathrm{c}}$ & $12(48)$ & $12(48)$ & $24(96)$ \\
\hline Theoretical foundation & $11(44)$ & $12(48)$ & $23(92)$ \\
\hline $\mathrm{n} \geq 40$ (for $C G$ and $E G^{\mathrm{d}}$ each) & $7(28)$ & $10(40)$ & $17(68)$ \\
\hline Evaluation of various mediators & $6(24)$ & $3(12)$ & $9(36)$ \\
\hline Time sequence or temporality & $1(4)$ & $0(0)$ & $1(4)$ \\
\hline Manipulation of mediators & $2(8)$ & $0(0)$ & $2(8)$ \\
\hline$P<.05$ & $13(52)$ & $12(48)$ & $25(100)$ \\
\hline
\end{tabular}

${ }^{\mathrm{a}} \mathrm{DHI} \mathrm{ISY}_{\mathrm{PS}}$ digital health interventions with a psychotherapeutic focus.

${ }^{\mathrm{b}} \mathrm{DHI}_{\mathrm{HP}}$ : digital health interventions with a focus on health promotion.

${ }^{\mathrm{c}} \mathrm{CG}$ : control group.

${ }^{\mathrm{d}}$ EG: experimental group. 


\section{Discussion}

\section{Principal Findings}

This systematic review, to the knowledge of the authors the first of its kind, comprehensively evaluated research on mediators and mechanisms of change in DHIs for common mental disorders in youth. Altogether, 25 studies were included in the review, that have examined 39 distinct mediators. Cognitive variables were found to be the most often investigated mediators, followed by a broad range of other mediators. Even though our eligibility criteria were not limited to a specific mental health condition in youth, only a rather low number of studies were identified by our systematic literature searches, a finding that corresponds to the limited evidence base of research on mechanisms of change in psychotherapy in general $[37,74]$, and for children and adolescents in specific [24,35,37], necessitating further high-quality research efforts to improve interventions and mental health care practices for this younger age group.

Remarkably, our findings indicate that the mediator category with the highest percentage of significant intervening variables was the affective or emotional mediator group $(4 / 4,100 \%)$. The proportions of significance in other mediator categories were by far less high and included combined cognitive $(13 / 19,68 \%)$, other $(3 / 8,37 \%)$, interpersonal $(1 / 4,25 \%)$, and parenting behavior-related mediators $(0 / 4,0 \%)$. The consistent nonsignificant findings on parenting behavior-related intervening variables are astonishing, as parenting behavior is otherwise thought to be of paramount importance in the treatment of behavioral problems in youth, both in conventional interventions delivered face-to-face [75] and in digital parent training alike [76,77]. Therefore, the findings of our study are in contrast to those of a systematic review [75], which revealed that in 45\% (39/86) of the included studies on face-to-face parent training programs, parenting behavior served as a mediator for the association between the intervention and symptom change in children. Furthermore, the importance of emotion regulation might be underestimated in (digital) psychotherapeutic interventions for children and adolescents, considering the consistent pattern of significant findings across studies in our review, as well as by allowing for comprehensive earlier research highlighting the overall importance of emotion regulation competencies for mental health in childhood and adolescence [78]. However, given the rather small number of mediation studies per category in our review, these findings need to be interpreted with caution and must be considered as preliminary. This is also owing to the rather heterogeneous evidence base, where included studies varied broadly in terms of the theoretical foundations of the intervention as well as the simultaneous consideration of various mental disorders, which may further restrict the comparability between studies. Nevertheless, a Wilcoxon rank-sum test revealed no differences in the sample sizes between studies that found at least one significant mediator and studies that found no significant mediator, suggesting that there is no effect of sample size on the evaluation of intervening variables, strengthening the robustness and validity of the findings on the mediators in this regard.
Importantly, participants were most often adolescents, with only $16 \%(4 / 25)$ of eligible studies evaluating interventions for children, suggesting an additional research gap for this younger age group. Here, all interventions for children were conducted with the involvement of parents, suggesting a crucial role of the accompanying human support in DHIs for younger children, which must be corroborated and further specified by forthcoming research $[12,79]$. In studies evaluating $\mathrm{DHI}_{\mathrm{HP}}$, only cognitive mediators (perceived norm and alcohol-related expectation) were investigated. This finding is consistent with prior research, where the cognitive mediator, perceived norm, was established as one of the most evaluated mediators in interventions for problematic drinking behaviors in adolescents and young adults delivered on site [80]. However, this result rather highlights the researcher's presumptions than the evidence base of the superior relevance of cognitive mediators over other, not yet well examined, affective and behavioral mediators.

The results of the RoB assessment indicated a rather limited overall study quality, with $76 \%$ (19/25) of the included studies rated with a high $R o B$, a finding that aligns with the review by Christ et al [81], in which 92\% (22/24) included studies on DHIs for adolescents and young adults were assessed with a high $R o B$. These findings on RoB2 might be largely due to the specifics of psychotherapy research [82], where masking of therapists or personnel and participants is difficult to achieve, as well as the more conservative novel RoB2 algorithm [83]. Of note, in our review, the mean study dropout rate was $18 \%$. Therefore, only a fraction of the included studies fulfilled the RoB 2 criterion that $95 \%$ of randomized participants' data should be available for data analysis. Although the current mean dropout rate in this review is rather small compared with other high dropout rates found in DHIs, the well-known issue of limited engagement still warrants future research to further investigate approaches to remedy (study and intervention) attrition [84,85]. In this particular field, primary studies in the review at hand may offer guidance and direction to more effective engagement in youth (Multimedia Appendix 2), such as interactive intervention components and age-appropriate content presentation in the form of puzzles, videos, or cartoons [12].

The results of the methodological quality assessment for process research revealed that most studies adhered to certain quality criteria satisfactorily (ie, using an RCT design and CG, evaluation of a strong statistical association, describing a theoretical foundation for mediators and sample size per trial group). However, in contrast, most primary studies did not experimentally manipulate the potential mediators, did not assess several mediators simultaneously, and did not evaluate the time sequence or temporal ordering of changes in mediators and outcomes. However, this latter criterion is considered to be of utmost importance for causal inferences and is sometimes referred to as the fifth step of mediation analysis [86]. Even though mediators and outcomes were assessed more than twice in $60 \%(15 / 25)$ of the included studies, only $4 \%(1 / 25)$ of the studies [47] actually conducted a statistical evaluation of the time sequence of cause and effect. Taken together, the findings of our review seem to be in line with those of other research $[24,44,45,83]$, pointing to important methodological 
shortcomings of mediation studies, which should be amended by future research. At this point, 1 high-quality RCT [58] sets an example, fulfilling 6 out of 8 quality criteria.

\section{Strengths and Limitations}

This systematic review offers several strengths, including a comprehensive literature search, as well as the broad consideration of common mental disorders and theoretical orientations, resulting in an extensive overview of the research on mediators and mechanisms of change for DHIs in children and adolescents conducted so far. Furthermore, with the differential consideration of the 2 categories of $\mathrm{DHI}_{\mathrm{PSY}}$ and $\mathrm{DHI}_{\mathrm{HP}}$, we intended to provide specific evidence-based information that might be valuable for digital psychotherapeutic and health promotion interventions alike. However, some limitations must be considered when interpreting the findings of this review. First, the number of eligible studies is rather small; the generalizability of the findings might be reduced as most studies were conducted in Western countries; these studies evaluated internet-based interventions; participants were predominantly female; and these studies relied on older participants. Second, only English language papers were included, and we did not incorporate gray literature in our study as recent findings indicated a negligible relevance of gray literature in systematic reviews [87]; further, publication bias cannot be ruled out. Third, although we only included RCT studies in our review (which might have led to an overestimation of the study quality in general, omitting other design studies with potentially lower methodological rigor), the RoB assessment indicated substantial shortcomings in the included studies. However, this finding should be weighed against the typical constraints of research on psychological interventions.

\section{Future Directions}

The following recommendations might be helpful for future mediation studies, aiming to advance our understanding of the working mechanisms of DHIs for youth. First, it is essential to avoid the methodological shortcomings outlined in the assessment of quality criteria for process research, especially with regard to the temporality of changes and experimental manipulation of mediators, both of which are key for the justification of causal inferences. Furthermore, future studies should resort to more sophisticated and current methods of mediation analysis (eg, Grimm et al [88] and Hofmann et al [89]), ideally capable of clarifying temporal precedence and illustrating the actual pattern of change [24]. Second, the therapeutic or working alliance (ie, the professional relationship between therapists and patients; eg, Grawe et al [90]) was not evaluated as a mediator in any of the included studies. However, the recent development of the working alliance inventory for digital interventions [91] may contribute to future process research, informing the evidence base of the effects of a digital therapeutic alliance in DHIs for youth [37,92]. Furthermore, mediators that have not been investigated so far, such as behavioral and biological variables, should be evaluated in future studies. At this point, the possibilities of novel technological methods in process research seem not to be fully exploited in this research field [37]. Passive sensing methodologies and digital phenotyping approaches with smartphones [93] might generate insights on behavioral and biological mechanisms in real life, in addition to the predominant information on cognitive variables derived from self-reports identified in the current review. Third, although worldwide about $90 \%$ of youth live in countries with low or medium income, $90 \%$ of RCTs investigating mental disorders in children and adolescents are conducted in high-income countries [1], mirroring the findings of the review at hand. In contrast, the presumed advantages of DHIs may be especially relevant in structurally weak and low-income countries. To overcome this contradiction, replication studies should aim to include and reach populations from low-income countries as well. Finally, our review revealed that mediators focusing on emotional and cognitive processes might be of paramount importance as potential mechanisms of change in DHIs for youth. However, the processes covered by these mediators varied to some extent. Thus, future studies focusing on both emotional and cognitive processes in a systematic way within one framework could be of great importance for the field.

\section{Conclusions}

This systematic review is the first to comprehensively investigate the mechanisms of change in different DHIs for youth. The key findings indicate that the largest group of examined mediators are cognitive variables, followed by an array of other mediator variables, including interpersonal, parenting behavior, and affective mediator categories. Of note, emotional and affective mediators consistently reached statistical significance across studies, whereas parenting-related mediators were evaluated constantly as nonsignificant. However, these findings must be considered cautiously, as we detected only a limited number of primary studies, despite including a broad range of mental disorders and interventions. Future studies should aim to lessen this research gap, ideally adhering to the quality criteria for process research and recent methods of mediation analyses, enabling more causally robust findings. These forthcoming studies might contribute to disentangling the therapeutic processes in DHIs, providing evidence-based knowledge to inform intervention development and augmented mental health care practices worldwide.

\section{Acknowledgments}

This work was supported by the German Federal Ministry of Education and Research (grant identification FKZ01KG1802). The funding source, the Federal Ministry of Education and Research, had no role in the study design, collection, analysis, or interpretation of the data, writing of the manuscript, or the decision to submit this paper for publication. 


\section{Authors' Contributions}

MD, SE, and HB developed the study design. SE and HN conducted the systematic literature searches, extracted the data, and rated the risk of bias and methodological quality criteria of included studies under the supervision of MD. MD wrote the first draft of the manuscript. All authors (MD, SE, HN, AL, AB, and HB) have contributed to the writing of the manuscript and have approved the final manuscript.

\section{Conflicts of Interest}

$\mathrm{AB}$ has received payment for consulting from Pro-Change Behavior Systems. All other authors (MD, SE, HN, AL, and HB) stated no conflicts of interest.

\section{Multimedia Appendix 1}

Search strings for Cochrane Central Register of Controlled Trials, Embase, MEDLINE, and PsycINFO in Ovid.

[DOCX File, 64 KB-Multimedia Appendix 1]

\section{Multimedia Appendix 2}

Study characteristics.

[DOCX File, 113 KB-Multimedia Appendix 2]

\section{Multimedia Appendix 3}

Studies with number of criteria met.

[DOCX File, 68 KB-Multimedia Appendix 3]

\section{References}

1. Kieling C, Baker-Henningham H, Belfer M, Conti G, Ertem I, Omigbodun O, et al. Child and adolescent mental health worldwide: evidence for action. Lancet 2011 Oct 22;378(9801):1515-1525. [doi: 10.1016/S0140-6736(11)60827-1] [Medline: 22008427]

2. Erskine HE, Moffitt TE, Copeland WE, Costello EJ, Ferrari AJ, Patton G, et al. A heavy burden on young minds: the global burden of mental and substance use disorders in children and youth. Psychol Med 2015 May;45(7):1551-1563 [FREE Full text] [doi: 10.1017/S0033291714002888] [Medline: 25534496]

3. Kessler RC, Amminger GP, Aguilar-Gaxiola S, Alonso J, Lee S, Ustün TB. Age of onset of mental disorders: a review of recent literature. Curr Opin Psychiatry 2007 Jul;20(4):359-364 [FREE Full text] [doi: 10.1097/YCO.0b013e32816ebc8c] [Medline: 17551351$]$

4. Costello EJ, He J, Sampson NA, Kessler RC, Merikangas KR. Services for adolescents with psychiatric disorders: 12-month data from the National Comorbidity Survey-Adolescent. Psychiatr Serv 2014 Mar 01;65(3):359-366 [FREE Full text] [doi: 10.1176/appi.ps.201100518] [Medline: 24233052]

5. Jörg F, Visser E, Ormel J, Reijneveld SA, Hartman CA, Oldehinkel AJ. Mental health care use in adolescents with and without mental disorders. Eur Child Adolesc Psychiatry 2016 May;25(5):501-508 [FREE Full text] [doi: 10.1007/s00787-015-0754-9] [Medline: 26275772]

6. Whitney DG, Peterson MD. US national and state-level prevalence of mental health disorders and disparities of mental health care use in children. JAMA Pediatr 2019 Apr 01;173(4):389-391 [FREE Full text] [doi: 10.1001/jamapediatrics.2018.5399] [Medline: 30742204]

7. Radez J, Reardon T, Creswell C, Lawrence PJ, Evdoka-Burton G, Waite P. Why do children and adolescents (not) seek and access professional help for their mental health problems? A systematic review of quantitative and qualitative studies. Eur Child Adolesc Psychiatry 2021 Feb;30(2):183-211 [FREE Full text] [doi: 10.1007/s00787-019-01469-4] [Medline: $\underline{31965309]}$

8. Kazdin AE, Blase SL. Rebooting psychotherapy research and practice to reduce the burden of mental illness. Perspect Psychol Sci 2011 Jan;6(1):21-37. [doi: 10.1177/1745691610393527] [Medline: 26162113]

9. Patel V, Flisher AJ, Hetrick S, McGorry P. Mental health of young people: a global public-health challenge. Lancet 2007 Apr 14;369(9569):1302-1313. [doi: 10.1016/S0140-6736(07)60368-7] [Medline: 17434406]

10. Wind TR, Rijkeboer M, Andersson G, Riper H. The COVID-19 pandemic: the 'black swan' for mental health care and a turning point for e-health. Internet Interv 2020 Apr;20:100317 [FREE Full text] [doi: 10.1016/j.invent.2020.100317] [Medline: 32289019]

11. United Nations Children's Fund (UNICEF). The State of the World's Children 2017 Children in a Digital World. New York, NY: United Nations; 2018. 
12. Domhardt M, Steubl L, Baumeister H. Internet- and mobile-based interventions for mental and somatic conditions in children and adolescents. Z Kinder Jugendpsychiatr Psychother 2020 Jan;48(1):33-46 [FREE Full text] [doi: 10.1024/1422-4917/a000625] [Medline: 30422059]

13. Lin J, Ebert DD, Lehr D, Berking M, Baumeister H. [Internet based cognitive behavioral interventions: state of the art and implementation possibilities in rehabilitation]. Rehabilitation (Stuttg) 2013 Jun;52(3):155-163. [doi: 10.1055/s-0033-1343491] [Medline: 23761204]

14. Lin J, Baumeister H. Internet- und mobilebasierte interventionen in der psychotherapie. Public Health Forum 2015 Sep 1;23(3):176-179. [doi: 10.1515/pubhef-2015-0063]

15. Berger T. The therapeutic alliance in internet interventions: a narrative review and suggestions for future research. Psychother Res 2017 Sep;27(5):511-524. [doi: 10.1080/10503307.2015.1119908] [Medline: 26732852]

16. Ebert DD, Zarski A, Christensen H, Stikkelbroek Y, Cuijpers P, Berking M, et al. Internet and computer-based cognitive behavioral therapy for anxiety and depression in youth: a meta-analysis of randomized controlled outcome trials. PLoS One 2015 Mar 18;10(3):e0119895 [FREE Full text] [doi: 10.1371/journal.pone.0119895] [Medline: 25786025]

17. Pennant ME, Loucas CE, Whittington C, Creswell C, Fonagy P, Fuggle P, Expert Advisory Group. Computerised therapies for anxiety and depression in children and young people: a systematic review and meta-analysis. Behav Res Ther 2015 Apr;67:1-18. [doi: 10.1016/j.brat.2015.01.009] [Medline: 25727678]

18. Podina IR, Mogoase C, David D, Szentagotai A, Dobrean A. A meta-analysis on the efficacy of technology mediated CBT for anxious children and adolescents. J Rat Emo Cognitive Behav Ther 2015 Nov 17;34(1):31-50. [doi: 10.1007/s10942-015-0228-5]

19. Vigerland S, Lenhard F, Bonnert M, Lalouni M, Hedman E, Ahlen J, et al. Internet-delivered cognitive behavior therapy for children and adolescents: a systematic review and meta-analysis. Clin Psychol Rev 2016 Dec;50:1-10 [FREE Full text] [doi: 10.1016/j.cpr.2016.09.005] [Medline: 27668988]

20. Hollis C, Falconer CJ, Martin JL, Whittington C, Stockton S, Glazebrook C, et al. Annual Research Review: digital health interventions for children and young people with mental health problems - a systematic and meta-review. J Child Psychol Psychiatry 2017 Apr;58(4):474-503. [doi: 10.1111/jcpp.12663] [Medline: 27943285]

21. Baumeister H, Reichler L, Munzinger M, Lin J. The impact of guidance on internet-based mental health interventions a systematic review. Internet Interv 2014 Oct;1(4):205-215. [doi: 10.1016/j.invent.2014.08.003]

22. Domhardt M, Geßlein H, von Rezori RE, Baumeister H. Internet- and mobile-based interventions for anxiety disorders: a meta-analytic review of intervention components. Depress Anxiety 2019 Mar;36(3):213-224. [doi: 10.1002/da.22860] [Medline: 30450811$]$

23. Webb TL, Joseph J, Yardley L, Michie S. Using the internet to promote health behavior change: a systematic review and meta-analysis of the impact of theoretical basis, use of behavior change techniques, and mode of delivery on efficacy. J Med Internet Res 2010 Feb 17;12(1):e4 [FREE Full text] [doi: 10.2196/jmir.1376] [Medline: 20164043]

24. Domhardt M, Steubl L, Boettcher J, Buntrock C, Karyotaki E, Ebert DD, et al. Mediators and mechanisms of change in internet- and mobile-based interventions for depression: a systematic review. Clin Psychol Rev 2021 Feb;83:101953. [doi: 10.1016/j.cpr.2020.101953] [Medline: 33422841]

25. Kazdin AE. Mediators and mechanisms of change in psychotherapy research. Annu Rev Clin Psychol 2007;3:1-27. [doi: 10.1146/annurev.clinpsy.3.022806.091432] [Medline: 17716046 ]

26. Kazdin AE, Nock MK. Delineating mechanisms of change in child and adolescent therapy: methodological issues and research recommendations. J Child Psychol Psychiatry 2003 Nov;44(8):1116-1129. [doi: 10.1111/1469-7610.00195] [Medline: 14626454]

27. MacKinnon DP, Fairchild AJ, Fritz MS. Mediation analysis. Annu Rev Psychol 2007;58:593-614 [FREE Full text] [doi: 10.1146/annurev.psych.58.110405.085542] [Medline: 16968208]

28. von Soest T, Hagtvet KA. Mediation analysis in a latent growth curve modeling framework. Struct Equ Modeling 2011 Apr 06;18(2):289-314. [doi: 10.1080/10705511.2011.557344]

29. Iacobucci D, Saldanha N, Deng X. A meditation on mediation: evidence that structural equations models perform better than regressions. J Consum Psychol 2007 Apr;17(2):139-153. [doi: 10.1016/s1057-7408(07)70020-7]

30. Baron RM, Kenny DA. The moderator-mediator variable distinction in social psychological research: conceptual, strategic, and statistical considerations. J Pers Soc Psychol 1986 Dec;51(6):1173-1182. [doi: 10.1037//0022-3514.51.6.1173] [Medline: 3806354]

31. Kraemer HC, Wilson GT, Fairburn CG, Agras WS. Mediators and moderators of treatment effects in randomized clinical trials. Arch Gen Psychiatry 2002 Oct;59(10):877-883. [doi: 10.1001/archpsyc.59.10.877] [Medline: 12365874]

32. Kazdin AE. Psychotherapy for children and adolescents. Annu Rev Psychol 2003;54:253-276. [doi: 10.1146/annurev.psych.54.101601.145105] [Medline: $\underline{12185210}$ ]

33. Weersing VR, Weisz JR. Mechanisms of action in youth psychotherapy. J Child Psychol Psychiatry 2002 Jan;43(1):3-29. [doi: 10.1111/1469-7610.00002] [Medline: 11848335]

34. Ng MY, DiVasto KA, Cootner S, Gonzalez N, Weisz JR. What do 30 years of randomized trials tell us about how psychotherapy improves youth depression? A systematic review of candidate mediators. Clin Psychol Sci Pract 2020 Aug 18:- (forthcoming). [doi: 10.1111/cpsp.12367] 
35. Schmidt SJ, Schimmelmann BG. Mechanisms of change in psychotherapy for children and adolescents: current state, clinical implications, and methodological and conceptual recommendations for mediation analysis. Eur Child Adolesc Psychiatry 2015 Mar;24(3):249-253. [doi: 10.1007/s00787-015-0698-0] [Medline: 25711288]

36. Andersson G, Titov N, Dear BF, Rozental A, Carlbring P. Internet-delivered psychological treatments: from innovation to implementation. World Psychiatry 2019 Feb;18(1):20-28 [FREE Full text] [doi: 10.1002/wps.20610] [Medline: 30600624]

37. Domhardt M, Cuijpers P, Ebert DD, Baumeister H. More light? Opportunities and pitfalls in digitalized psychotherapy process research. Front Psychol 2021 Mar 19;12:544129 [FREE Full text] [doi: 10.3389/fpsyg.2021.544129] [Medline: 33815184]

38. Moher D, Liberati A, Tetzlaff J, Altman DG, PRISMA Group. Preferred reporting items for systematic reviews and meta-analyses: the PRISMA statement. PLoS Med 2009 Jul 21;6(7):e1000097 [FREE Full text] [doi: 10.1371/journal.pmed.1000097] [Medline: 19621072]

39. Mediators and mechanisms of change in digital health interventions for mental disorders in children and adolescents. Center for Open Science. URL: https://osf.io/vds4e/ [accessed 2021-11-09]

40. Thabrew H, Stasiak K, Hetrick S, Wong S, Huss J, Merry S. E-Health interventions for anxiety and depression in children and adolescents with long-term physical conditions. Cochrane Database Syst Rev 2018 Aug 15;8(8):CD012489 [FREE Full text] [doi: 10.1002/14651858.CD012489.pub2] [Medline: $\underline{30110718]}$

41. Covidence systematic review management. Brown University. URL: https://libguides.brown.edu/Reviews/Covidence [accessed 2021-10-24]

42. Sterne JA, Savović J, Page MJ, Elbers RG, Blencowe NS, Boutron I, et al. RoB 2: a revised tool for assessing risk of bias in randomised trials. BMJ 2019 Aug 28;366:14898. [doi: 10.1136/bmj.14898] [Medline: $\underline{31462531]}$

43. RStudio: integrated development environment for R. R Studio. URL: https://www.rstudio.com/products/rstudio/ \#: :text=RStudio\%20is\%20an\%20integrated\%20development,history\%2C\%20debugging\%20and\%20workspace\%20management [accessed 2021-10-24]

44. Lemmens LH, Müller VN, Arntz A, Huibers MJ. Mechanisms of change in psychotherapy for depression: an empirical update and evaluation of research aimed at identifying psychological mediators. Clin Psychol Rev 2016 Dec;50:95-107. [doi: 10.1016/j.cpr.2016.09.004] [Medline: 27770716]

45. Moreno-Peral P, Bellón JÁ, Huibers MJ, Mestre JM, García-López LJ, Taubner S, et al. Mediators in psychological and psychoeducational interventions for the prevention of depression and anxiety. A systematic review. Clin Psychol Rev 2020 Mar;76:101813. [doi: 10.1016/j.cpr.2020.101813] [Medline: 32045780]

46. Anderson RE, Spence SH, Donovan CL, March S, Prosser S, Kenardy J. Working alliance in online cognitive behavior therapy for anxiety disorders in youth: comparison with clinic delivery and its role in predicting outcome. J Med Internet Res 2012 Jun 28;14(3):e88 [FREE Full text] [doi: 10.2196/jmir.1848] [Medline: 22789657]

47. de Bruin EJ, Bögels SM, Oort FJ, Meijer AM. Improvements of adolescent psychopathology after insomnia treatment: results from a randomized controlled trial over 1 year. J Child Psychol Psychiatry 2018 May;59(5):509-522. [doi: 10.1111/jcpp.12834] [Medline: 29052846]

48. Collins SE, Carey KB, Sliwinski MJ. Mailed personalized normative feedback as a brief intervention for at-risk college drinkers. J Stud Alcohol 2002 Sep;63(5):559-567. [doi: 10.15288/jsa.2002.63.559] [Medline: 12380852]

49. Denis D, Eley TC, Rijsdijk F, Zavos HM, Keers R, Espie CA, et al. Is digital cognitive behavioural therapy for insomnia effective in treating sub-threshold insomnia: a pilot RCT. Sleep Med 2020 Feb;66:174-183. [doi: 10.1016/j.sleep.2019.10.007] [Medline: 31901759]

50. Doumas DM, McKinley LL, Book P. Evaluation of two Web-based alcohol interventions for mandated college students. J Subst Abuse Treat 2009 Jan;36(1):65-74. [doi: 10.1016/j.jsat.2008.05.009] [Medline: 18657941]

51. Doumas DM, Workman C, Smith D, Navarro A. Reducing high-risk drinking in mandated college students: evaluation of two personalized normative feedback interventions. J Subst Abuse Treat 2011 Jun;40(4):376-385. [doi:

10.1016/j.jsat.2010.12.006] [Medline: 21295938]

52. Dunn ME, Fried-Somerstein A, Flori JN, Hall TV, Dvorak RD. Reducing alcohol use in mandated college students: a comparison of a Brief Motivational Intervention (BMI) and the Expectancy Challenge Alcohol Literacy Curriculum (ECALC). Exp Clin Psychopharmacol 2020 Feb;28(1):87-98. [doi: 10.1037/pha0000290] [Medline: 31008641]

53. Geisner IM, Neighbors C, Larimer ME. A randomized clinical trial of a brief, mailed intervention for symptoms of depression. J Consult Clin Psychol 2006 Apr;74(2):393-399. [doi: 10.1037/0022-006X.74.2.393] [Medline: 16649884]

54. Ghaderi A, Kadesjö C, Björnsdotter A, Enebrink P. Randomized effectiveness Trial of the Family Check-Up versus Internet-delivered Parent Training (iComet) for families of children with conduct problems. Sci Rep 2018 Jul 31;8(1):11486 [FREE Full text] [doi: 10.1038/s41598-018-29550-z] [Medline: $\underline{\text { 30065246] }}$

55. Gilmore AK, Bountress KE. Reducing drinking to cope among heavy episodic drinking college women: secondary outcomes of a web-based combined alcohol use and sexual assault risk reduction intervention. Addict Behav 2016 Oct;61:104-111 [FREE Full text] [doi: 10.1016/j.addbeh.2016.05.007] [Medline: 27262965]

56. Hintz S, Frazier PA, Meredith L. Evaluating an online stress management intervention for college students. J Couns Psychol 2015 Apr;62(2):137-147. [doi: 10.1037/cou0000014] [Medline: 24635586] 
57. Jouriles EN, Brown AS, Rosenfield D, McDonald R, Croft K, Leahy MM, et al. Improving the effectiveness of computer-delivered personalized drinking feedback interventions for college students. Psychol Addict Behav 2010 Dec;24(4):592-599. [doi: 10.1037/a0020830] [Medline: 21198222]

58. Kauer SD, Reid SC, Crooke AH, Khor A, Hearps SJ, Jorm AF, et al. Self-monitoring using mobile phones in the early stages of adolescent depression: randomized controlled trial. J Med Internet Res 2012 Jun 25;14(3):e67 [FREE Full text] [doi: 10.2196/jmir.1858] [Medline: 22732135]

59. LaFreniere LS, Newman MG. The impact of uncontrollability beliefs and thought-related distress on ecological momentary interventions for generalized anxiety disorder: a moderated mediation model. J Anxiety Disord 2019 Aug;66:102113 [FREE Full text] [doi: 10.1016/j.janxdis.2019.102113] [Medline: $\underline{31362145]}$

60. Levin ME, Haeger JA, Pierce BG, Twohig MP. Web-based acceptance and commitment therapy for mental health problems in college students: a randomized controlled trial. Behav Modif 2017 Jan 01;41(1):141-162. [doi: 10.1177/0145445516659645] [Medline: 27440189]

61. Lewis MA, Patrick ME, Litt DM, Atkins DC, Kim T, Blayney JA, et al. Randomized controlled trial of a web-delivered personalized normative feedback intervention to reduce alcohol-related risky sexual behavior among college students. $\mathbf{J}$ Consult Clin Psychol 2014 Jun;82(3):429-440 [FREE Full text] [doi: 10.1037/a0035550] [Medline: 24491076]

62. Murphy JG, Dennhardt AA, Skidmore JR, Martens MP, McDevitt-Murphy ME. Computerized versus motivational interviewing alcohol interventions: impact on discrepancy, motivation, and drinking. Psychol Addict Behav 2010 Dec;24(4):628-639 [FREE Full text] [doi: 10.1037/a0021347] [Medline: 21198224]

63. Neighbors C, Lewis MA, Atkins DC, Jensen MM, Walter T, Fossos N, et al. Efficacy of web-based personalized normative feedback: a two-year randomized controlled trial. J Consult Clin Psychol 2010 Dec;78(6):898-911 [FREE Full text] [doi: 10.1037/a0020766] [Medline: 20873892]

64. Riley AR, Duke DC, Freeman KA, Hood KK, Harris MA. Depressive symptoms in a trial behavioral family systems therapy for diabetes: a post hoc analysis of change. Diabetes Care 2015 Aug;38(8):1435-1440. [doi: 10.2337/dc14-2519] [Medline: 26015558]

65. Spence SH, Donovan CL, March S, Kenardy JA, Hearn CS. Generic versus disorder specific cognitive behavior therapy for social anxiety disorder in youth: a randomized controlled trial using internet delivery. Behav Res Ther 2017 Mar;90:41-57. [doi: 10.1016/j.brat.2016.12.003] [Medline: 27988427]

66. van der Zanden R, Galindo-Garre F, Curie K, Kramer J, Cuijpers P. Online cognitive-based intervention for depression: exploring possible circularity in mechanisms of change. Psychol Med 2014 Apr;44(6):1159-1170. [doi: 10.1017/S003329171300175X] [Medline: 23866103]

67. Wade SL, Cassedy AE, Shultz EL, Zang H, Zhang N, Kirkwood MW, et al. Randomized clinical trial of online parent training for behavior problems after early brain injury. J Am Acad Child Adolesc Psychiatry 2017 Nov;56(11):930-9.e2. [doi: 10.1016/j.jaac.2017.09.413] [Medline: 29096775]

68. Walters ST, Vader AM, Harris TR. A controlled trial of web-based feedback for heavy drinking college students. Prev Sci 2007 Mar;8(1):83-88. [doi: 10.1007/s11121-006-0059-9] [Medline: 17136461]

69. Wilksch SM, O'Shea A, Wade TD. Depressive symptoms, alcohol and other drug use, and suicide risk: prevention and treatment effects from a two-country online eating disorder risk reduction trial. Int J Eat Disord 2019 Feb;52(2):132-141. [doi: 10.1002/eat.23005] [Medline: 30582194]

70. Young CM, Neighbors C. Incorporating writing into a personalized normative feedback intervention to reduce problem drinking among college students. Alcohol Clin Exp Res 2019 May;43(5):916-926 [FREE Full text] [doi: 10.1111/acer.13995] [Medline: $\underline{\text { 30817010] }}$

71. Preacher KJ, Hayes AF. Asymptotic and resampling strategies for assessing and comparing indirect effects in multiple mediator models. Behav Res Methods 2008 Aug;40(3):879-891. [doi: 10.3758/brm.40.3.879] [Medline: 18697684]

72. Judd CM, Kenny DA, McClelland GH. Estimating and testing mediation and moderation in within-subject designs. Psychol Methods 2001 Jun;6(2):115-134. [doi: 10.1037/1082-989x.6.2.115] [Medline: 11411437]

73. Landis JR, Koch GG. The measurement of observer agreement for categorical data. Biometrics 1977 Mar;33(1):159-174. [Medline: $\underline{843571]}$

74. Cuijpers P, Reijnders M, Huibers MJ. The role of common factors in psychotherapy outcomes. Annu Rev Clin Psychol 2019 May 07;15:207-231. [doi: 10.1146/annurev-clinpsy-050718-095424] [Medline: 30550721]

75. Forehand R, Lafko N, Parent J, Burt KB. Is parenting the mediator of change in behavioral parent training for externalizing problems of youth? Clin Psychol Rev 2014 Dec;34(8):608-619 [FREE Full text] [doi: 10.1016/j.cpr.2014.10.001] [Medline: 25455625]

76. Baumel A, Pawar A, Kane JM, Correll CU. Digital parent training for children with disruptive behaviors: systematic review and meta-analysis of randomized trials. J Child Adolesc Psychopharmacol 2016 Oct;26(8):740-749. [doi: 10.1089/cap.2016.0048] [Medline: 27286325]

77. Baumel A, Mathur N, Pawar A, Muench F. Psychosocial interventions for children with externalized behavior problems: an updated meta-analysis of moderator effects. J Child Fam Stud 2021 Jan 07;30(1):65-86. [doi: 10.1007/s10826-020-01863-6] 
78. Compas BE, Jaser SS, Bettis AH, Watson KH, Gruhn MA, Dunbar JP, et al. Coping, emotion regulation, and psychopathology in childhood and adolescence: a meta-analysis and narrative review. Psychol Bull 2017 Sep;143(9):939-991 [FREE Full text] [doi: $10.1037 /$ bul0000110] [Medline: 28616996$]$

79. Domhardt M, Schröder A, Geirhos A, Steubl L, Baumeister H. Efficacy of digital health interventions in youth with chronic medical conditions: a meta-analysis. Internet Interv 2021 Feb 25;24:100373 [FREE Full text] [doi:

10.1016/j.invent.2021.100373] [Medline: $\underline{33732626]}$

80. Reid AE, Carey KB. Interventions to reduce college student drinking: state of the evidence for mechanisms of behavior change. Clin Psychol Rev 2015 Aug;40:213-224 [FREE Full text] [doi: 10.1016/j.cpr.2015.06.006] [Medline: 26164065]

81. Christ C, Schouten MJ, Blankers M, van Schaik DJ, Beekman AT, Wisman MA, et al. Internet and computer-based cognitive behavioral therapy for anxiety and depression in adolescents and young adults: systematic review and meta-analysis. J Med Internet Res 2020 Sep 25;22(9):e17831 [FREE Full text] [doi: 10.2196/17831] [Medline: 32673212]

82. Munder T, Barth J. Cochrane's risk of bias tool in the context of psychotherapy outcome research. Psychother Res 2018 May;28(3):347-355. [doi: 10.1080/10503307.2017.1411628] [Medline: 29224503]

83. Domhardt M, Nowak H, Engler S, Baumel A, Grund S, Mayer A, et al. Therapeutic processes in digital interventions for anxiety: a systematic review and meta-analytic structural equation modeling of randomized controlled trials. Clin Psychol Rev 2021 Sep 13;90:102084. [doi: 10.1016/j.cpr.2021.102084] [Medline: 34610493]

84. Torous J, Lipschitz J, Ng M, Firth J. Dropout rates in clinical trials of smartphone apps for depressive symptoms: a systematic review and meta-analysis. J Affect Disord 2020 Feb 15;263:413-419. [doi: 10.1016/j.jad.2019.11.167] [Medline: 31969272$]$

85. Melville KM, Casey LM, Kavanagh DJ. Dropout from internet-based treatment for psychological disorders. Br J Clin Psychol 2010 Nov;49(Pt 4):455-471. [doi: 10.1348/014466509X472138] [Medline: 19799804]

86. Johansson P, Høglend P, Ulberg R, Amlo S, Marble A, Bøgwald KP, et al. The mediating role of insight for long-term improvements in psychodynamic therapy. J Consult Clin Psychol 2010 Jun;78(3):438-448. [doi: 10.1037/a0019245] [Medline: 20515219]

87. Hartling L, Featherstone R, Nuspl M, Shave K, Dryden DM, Vandermeer B. Grey literature in systematic reviews: a cross-sectional study of the contribution of non-English reports, unpublished studies and dissertations to the results of meta-analyses in child-relevant reviews. BMC Med Res Methodol 2017 Apr 19;17(1):64 [FREE Full text] [doi: 10.1186/s12874-017-0347-z] [Medline: 28420349]

88. Grimm KJ, Ram N. Latent growth and dynamic structural equation models. Annu Rev Clin Psychol 2018 May 07;14:55-89. [doi: 10.1146/annurev-clinpsy-050817-084840] [Medline: 29734829]

89. Hofmann SG, Curtiss JE, Hayes SC. Beyond linear mediation: toward a dynamic network approach to study treatment processes. Clin Psychol Rev 2020 Mar;76:101824 [FREE Full text] [doi: 10.1016/j.cpr.2020.101824] [Medline: 32035297]

90. Straker N. Psychodynamic psychotherapy for cancer patients. J Psychother Pract Res 1997 Nov 25;7(1):1-9 [FREE Full text] [doi: 10.1080/10503309712331331843] [Medline: 9407471]

91. Herrero R, Vara MD, Miragall M, Botella C, García-Palacios A, Riper H, et al. Working Alliance Inventory for Online Interventions-Short Form (WAI-TECH-SF): the role of the therapeutic alliance between patient and online program in therapeutic outcomes. Int J Environ Res Public Health 2020 Aug 25;17(17):6169 [FREE Full text] [doi: 10.3390/ijerph17176169] [Medline: 32854381]

92. Henson P, Wisniewski H, Hollis C, Keshavan M, Torous J. Digital mental health apps and the therapeutic alliance: initial review. BJPsych Open 2019 Jan;5(1):e15 [FREE Full text] [doi: 10.1192/bjo.2018.86] [Medline: $\underline{30762511]}$

93. Baumeister H, Montag C. Digital Phenotyping and Mobile Sensing: New Developments in Psychoinformatics. Switzerland: Springer Nature; 2019.

\section{Abbreviations}

CG: control group

DHI: digital health intervention

DHIHP: digital health intervention with a focus on health promotion

DHIPSY: digital health intervention with a psychotherapeutic focus

RCT: randomized controlled trial

RoB: risk of bias 
Edited by R Kukafka; submitted 20.04.21; peer-reviewed by J Apolinário-Hagen, M Rassenhofer; comments to author 21.05.21; revised version received 14.07.21; accepted 27.07.21; published 26.11 .21

Please cite as:

Domhardt M, Engler S, Nowak H, Lutsch A, Baumel A, Baumeister H

Mechanisms of Change in Digital Health Interventions for Mental Disorders in Youth: Systematic Review

J Med Internet Res 2021;23(11):e29742

URL: https://www.jmir.org/2021/11/e29742

doi: $10.2196 / 29742$

PMID:

CMatthias Domhardt, Sophie Engler, Hannah Nowak, Arne Lutsch, Amit Baumel, Harald Baumeister. Originally published in the Journal of Medical Internet Research (https://www.jmir.org), 26.11.2021. This is an open-access article distributed under the terms of the Creative Commons Attribution License (https://creativecommons.org/licenses/by/4.0/), which permits unrestricted use, distribution, and reproduction in any medium, provided the original work, first published in the Journal of Medical Internet Research, is properly cited. The complete bibliographic information, a link to the original publication on https://www.jmir.org/, as well as this copyright and license information must be included. 